\title{
COST-EFFECTIVENESS OF SAILCLOTH SELECTION FOR DIFFERENT CLASSES, TYPES AND SPECIES OF SAILING BOATS
}

\author{
Svitlana Yeroshkina \\ Department of Economic Theory and Entrepreneurship of the Marine Transport \\ National University "Odessa Maritime Academy" \\ 8 Didrikhsona str., Odessa, Ukraine, 65029 \\ svitlanayeroshkina@ukr.net
}

\begin{abstract}
Results over of theoretical analysis for the selection of corresponding basic material of sail clothes fabric for a different classes, types and views of sailing boats are given in the article.

Sailing boats needs the proper of yachting equipment, that goes both with the manipulation of boats and rigging (in accordance of views, classes and types of sailing boats). The material for sailing is elected by participants of competitions depending of the area of navigation, the strength of wind, the whole distances and boat's possibilities, coming from technical criteria and parameters of the boats.

Full analysis of economic efficiency is conducted and price politics of different material's types for sails in accordance with its chemical composition is analyzed. The most effective type of factory fabric is certain for sewing of sails for racing boats. For a deep scientific analysis and practical realization of the investigated process an accent is done on the exposure of the most popular sailing sailcloth materials used only on the famous world regattas.

These results are very important and needed foremost for the first-class skippers of modern world racing boats, to identify most practical and super persistent to the wind, the sun, salt water materials that use in sewing of racing sails. Necessary analyses and descriptions of scientific article concerning sewing of racing sails also will be useful to the yachtsmen that only begin the way in the world of cruise yachting and sporting yachting races. Importance of faithful direction at the choice of material for sails is done not only for the decision element of victories in races and regattas, but also for an answer on many questions, constrained concerning speed of boat, norm of coverage of sails and, in the end, with maneuverability, boat speed.
\end{abstract}

Keywords: yachting, sails, racing, sailing boat, yacht, materials, Tyvek, Carbon, Dyneema, Vectran, Spectra, sailing.

\section{Introduction}

Today world yachting has a powerful fleet, that consists of the highly speed boats, equipped by modern navigation devices and devices for moving of transatlantic charter cruising yachts, LUX class yachts, NEO class yachts, transatlantic explorer class yachts, done from to the decks from teak and masts from steel, armed rigged by the last types of sail clothes (Vectran or fortified Kevlar), has modern helicopter pads, mini underwater submarine onboard, glass swimming pools, cinemas, ice rings, tropical gardens and sky tracks.

In the world of sailing there are main groups of racing boats:

- Cruising yachts on which measurements are made in accordance with the systems of IRC(CHS), PHRF, IMS;

- Cruisers;

- Racing yachts “of level” classes ILC, IRM, IMS;

- "Racers";

- Free monotype classes and participating in competitions without handicap;

- Sports boats, which are measured with the system SBR;

- Sports monotypes, taking into account that they racing in groups [1-4].

All boats, sailing yachts, motor-sailing and sailing-motor yachts in general for world classification's regattas are divided into following categories:

- Category A Ocean-boat ocean sailing, which have a direct rig, it's length more than $40 \mathrm{~m}$ and has withstand wind force over $8 \mathrm{~B}(>20 \mathrm{~m} / \mathrm{s})$, the height of waves over 4 meters;

- Category B Offshore-the wind under $8 \mathrm{~B}$ and the height of the wave before 4 meters inclusive; 
- Category C Inshore allocated on: coastal waters, bays, lakes, where the wind before 6B and the wave up to 2 meters;

- Category D Sheltered Waters allocated on: closed waters, where the wind before 4B and the wave up to $0.5 \mathrm{~m}$. Categories established by the CE Directive number 94/35/EC and developed under the name The Institute Recreational Craft (IRC) [2-5].

The type of yacht include: yachts for coastal races; deck-cruisers; cruising- racing yacht; racing yacht seas; RIBs; mega yacht and other [2-5].

By the navigation area all yachts are divided into: around of the world; oceanic; marine; local. Different types of cloth are used for different sail types, boats, and the type of sailing. Yachting classes has different sails for racing.

To define what type of fabric (sail clothes) will use for a certain sail, activity of sailing boats, the climate, area of navigation, use of boat area, it will have to consider the desire of skipper.

The most and main quality of the sailing cloth fabric must be adjusted firmness to give a resistance to UV elimination, because the UV rays are a damage is a most problem for yachting sails.

\section{Material and Methods}

Material for sewing of sail clothes is chosen for own by a desire depending on the area of navigation, to strength of wind, moving by the distance and possibilities of boat after its technical criteria. The sail cloth coverage is especially receptive to sea salt, because it is weakened by external influencing factors, foremost UV degradation. The fabric sail clothes need very high skills, because even problems take place every race. Yachting sport imposes duties in relation to fabric and it is important, that fibers must be very strong. The sail clothes coverage very important for success in racing. Using the new models of fabric to make sail, maybe, to give an answer for anything problems on duration of age of fibers for sailing.

Today in the world there is enough known companies involved in high-level sailing industry. They work closely with the chemical industry. Therefore, these companies have sufficient knowledge and skills to create new models of high-fiber sails [2-7]. There are general requirements in relation to selection of sails that must adhere to the terms of sewing and follow sewing at the order of sails:

1) cost;

2) strength. Higher is better for sails;

3) high elasticity modulus: elastic stretch resistance. Higher is better for upwind sails. Sailcloth must be ability to resist stretching under load;

4) the long term stretch of a fiber or fabric. A material with creep may have a superior modulus;

5) air tightness;

6) creep. The long term stretch of a fiber or fabric. A material with creep may have a superior modulus;

7) protection from UV lights.

There are many fabrics and materials for sewing of sails. But it is necessary not only sew from quality material, it is necessary that material is easy, but at the same time strong, capable to overcome pressure powerful wind and not torn.

Weight is a main method of classification of sailing clothes. In yachting world sport there are two methods of interlacing of fibers:

- balanced (a longitudinal yarn after length and crossing yarn has the same weight and diameter);

- unbalanced (one of yarn most than other and heavier by the weight. More heavy yarns are used only one-way. It's named "crosscut". It especially topically in relation to main sail and high aspects of loading during work with sails [6-13]).

Modern yachting sailing fibers has more heavy yarn in a sufficient amount (through material). Fillers help to abbreviate a stretch, bridging gap between yarns. But, if to do treatment rudely, fillers can break. The structure of sail can be presented in the form (prepared by author) 
where: sail - a sheet of material attached to a pole on a boat to catch the wind and make the boar move (Cambridge Dictionary); design - to draw plans for something (Cambridge Dictionary); construction (the work of building or making something (Cambridge Dictionary); attributes of the fibers - a quality or characteristic of fibers (Cambridge Dictionary); sailcloth - material for sails.

The basis in the selection of sail clothes gave in the book of "The New Book of Sail Trim" by Ken Textor. Many descriptions of sails were given in the article by Peter Mahr in "What Goes Into Sailcloth". Today there are six key factors for the estimation of fibers and it's fitness in the sailing fibers for racing:

1. Profitability after some time (Fig. 1).

2. UV protection (Fig. 2).

3. Stretch.

4. Elasticity: fibers with a creep, maybe, have the superior module, but loses the form through some time.

5. Elasticity is on a break (stretched).

6. Ability to resist stretching [8-13].

7. Weight.

8. Damage from washing.

What kinds of sail cloth use in such famous world sailing races as: Cup of America, Sydney-Hobart Ocean Yacht Race, Volvo Ocean Race, Transpacific Yacht Race, Clipper Round the World Race, Global Challenge, Vendée Globe, Regatta Velux 5 Oceans, Regatta The Tall Ship's Races Baltic, Rolex Fastnet Race, Bermuda Race, Rolex Transatlantic Challenge, etc.?

- Volvo Ocean Race: sails in the Volvo Ocean 65 were a world leading company does on sewing of sails of North Sails, using front-rank module technology $3 \mathrm{di}$, and forms the technology in Nevada. In 2017-2018 the new sail of J0 will be used in a race, except for stormy, all sails were built under the process of North Sails'3Di, using in good time the ribbons done from yellow Twaron Aramid and white fibers of Dyneema SK75(Yellow RAW760). The Carbon was not used in material of sails, as it was able to interfere with signals to meet and from companions necessary for communications and communication of data.

- America's Cup: America's Cup - one of the most famous races in the world. The boats of AC72 have 72 feet long with masts, and in high a 131 foot, where weight of every boat more than 13,000. The sail have $260 \mathrm{~m}^{2}$, made from hard material of traditional linen, can generate 7 tone of force more than, when terms of wind good. In AC72 designer, hard sails allow to control a yacht that goes under a sail. Sails are built by look like the wings of airplane [5].

- Sydney-Hobart Ocean Yacht Race: In 1945 sails were made from cotton. Today, even the rigging on yachts, which holds up the mast, has gone from wire to stainless, stainless rod to high tensile rod and is now to carbon. Every yacht also fitted with new sails made from a revolutionary, non-stretch, ultra-stretch.

- Transpacific Yacht Race: in monohull and multihull competition use different ultra-modulus sails.

- Clipper Round the World Race: it's a race without equal - 40,000 nautical mile race around the world on a 70-foot ocean racing yacht. Sir Robin Knox-Johnston said about the race: "You will never conquer or master the Ocean but you can endure it. Mother Nature is an unforgiving mistress, always with one last trick up her sleeve for you when you least expect it". Hyde's sails have been performing in the big boat arena for many years, where the company has successfully applied the expertise to produce race-winning sails of the highest quality.

- Vendée Globe: the IMOCA60 is the most powerful monohull in the world by a solo sailor at the "non-stop" distance. Famous skippers in Vendée Globe racing use the North Sails 3D. North Sails holds the patents for 3Di technology, and its Spread Filament technology which offers maximum material efficiently and resistance to stretch. Factors such as thermoset glue and the absence of Mylar film make 3Di the highest performing, most durable sail ever produced, etc. 


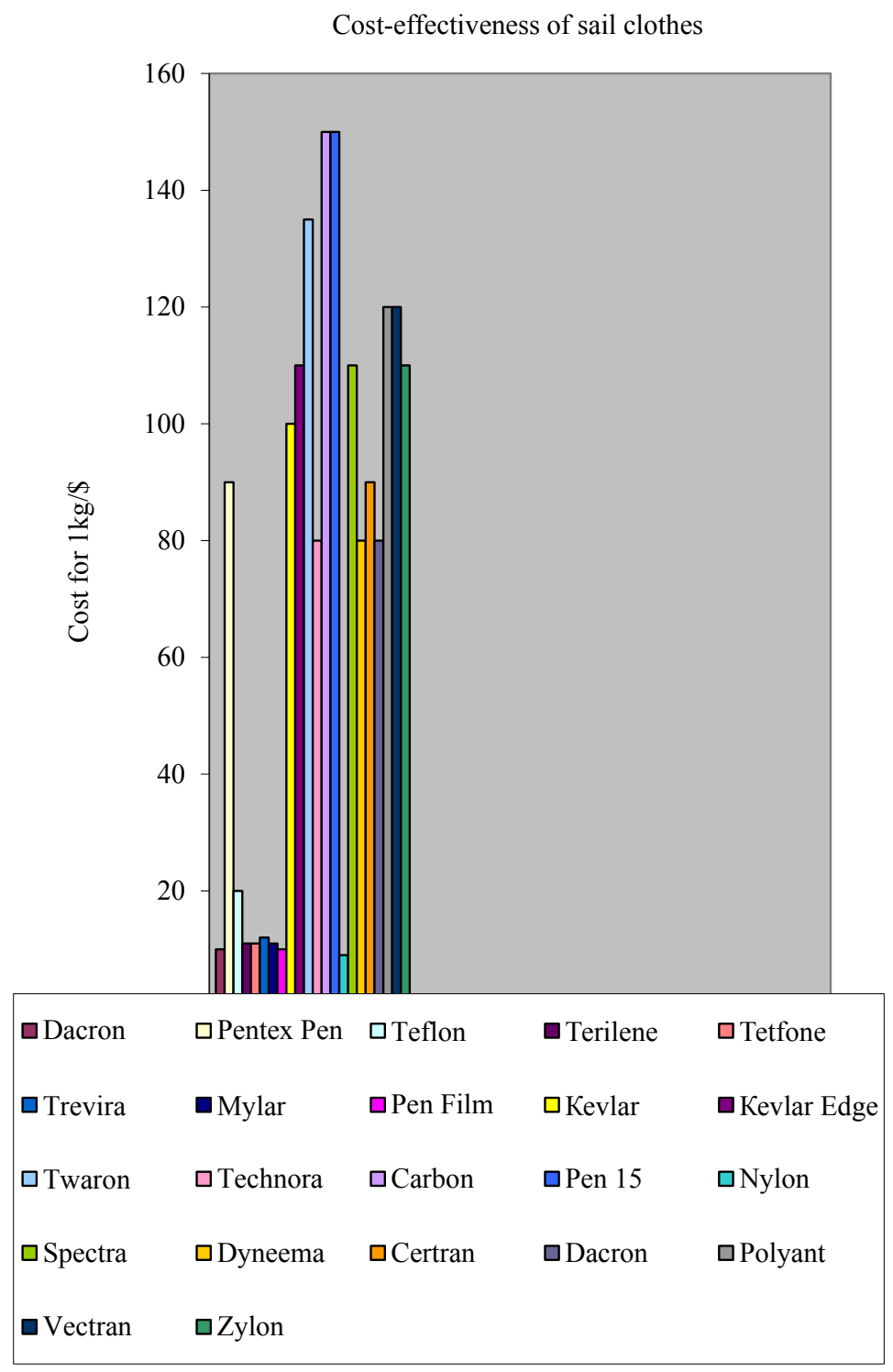

Fig. 1. Cost-effectiveness of sailcloth (origin: prepared by the author based on [2-5])

All materials are classified by types. The main fibers in world's yachting are:

- Class Synthetic Fiber: Polyester (Dacron, Type52, Terylene, Tetoron, Trevira, Diolen). The Polyester "was born" in 1950-s. But by far the most commonly used material for leisure boating sails are the various types of Woven Polyester. Polyethylene named as Dacron is the most popular type of sail cloth for a reasonable price.

Polyester sailcloth fabrics are sold under various trade names such as Terylene, Tetoron, Trevira, Diolen as well as Dacron. Polyester's Class includes excellent resiliency, low cost, high abrasion resistance and high UV resistance. Over time it will stretch and become a bit baggy but while it might lose its efficiency, it will still be useable. For cruising yachts the sailcloth has very durability fibers.

- Class Aramids Synthetic (Kevlar, Twaron, Technora). Aramids started in 1970-s. It is stronger than steel for its weight and has a modulus that is five times greater than the Polyester. But Kevlar has poor UV resistance and rapid loss of strength with flexing. This class is most often used as bias support (X-ply) in laminate sailcloth [2-5, 8-13].

- Class Polyethylenes (Certran, Dyneema, PEN Fiber (Polyethylene Naphthalate, Pentex, Spectra)) include superior resistance to flex fatigue and UV lights degradation and a tendency to 
creep. This class is often used by European sailcloth manufacturers. Laminates are a lower-cost option. This class offers good UV resistance and has very high initial modulus numbers.

- Liquid Crystal Polymer (Vectran, PBO (Zylon)). Vectran and Zylon has a high thermal stability, low creep, high chemical resistance, high cut and abrasion resistance and excellent resistance to stretch after repeated folding. But it has poor resistance to UV lights.

- Class Carbon Fibers is essentially unaffected by UV exposure. Carbon's Class used successfully in the America's Cup. The Carbon fiber laminates provide exceptionally low stretch for weight. Developed carbon sailcloth styles have paired high modulus carbon fiber with more durable Aramid, Spectra and Vectran fibers without sacrificing low stretch [2-5, 8-13].

- Class Films (Mylar, Pen Film) is a Mylar is the most common film used in laminated sailcloth. PEN film is stronger than Mylar film. But PEN film is less resistant to abuse and reduces the working life of the sail.

- Class Nylon Fiber started from 1938. Nylon, while it is cheap, light and strong, is normally only used for spinnakers and cruising chutes because it does tend to stretch. It's used in radial and asymmetrical spinnakers. But Nylon isn't good resistance to stretch and is more susceptible to UV lights.

- Class Laminated Fiber has a high price and the process of sail making is more complicated. Laminates are made by gluing together numerous layers of scrim, extruded plastic, wood, flax, hemp or cotton canvas. It's tending to be stiff to damage from flogging. This class also requires a great deal of expertise when building the sail.

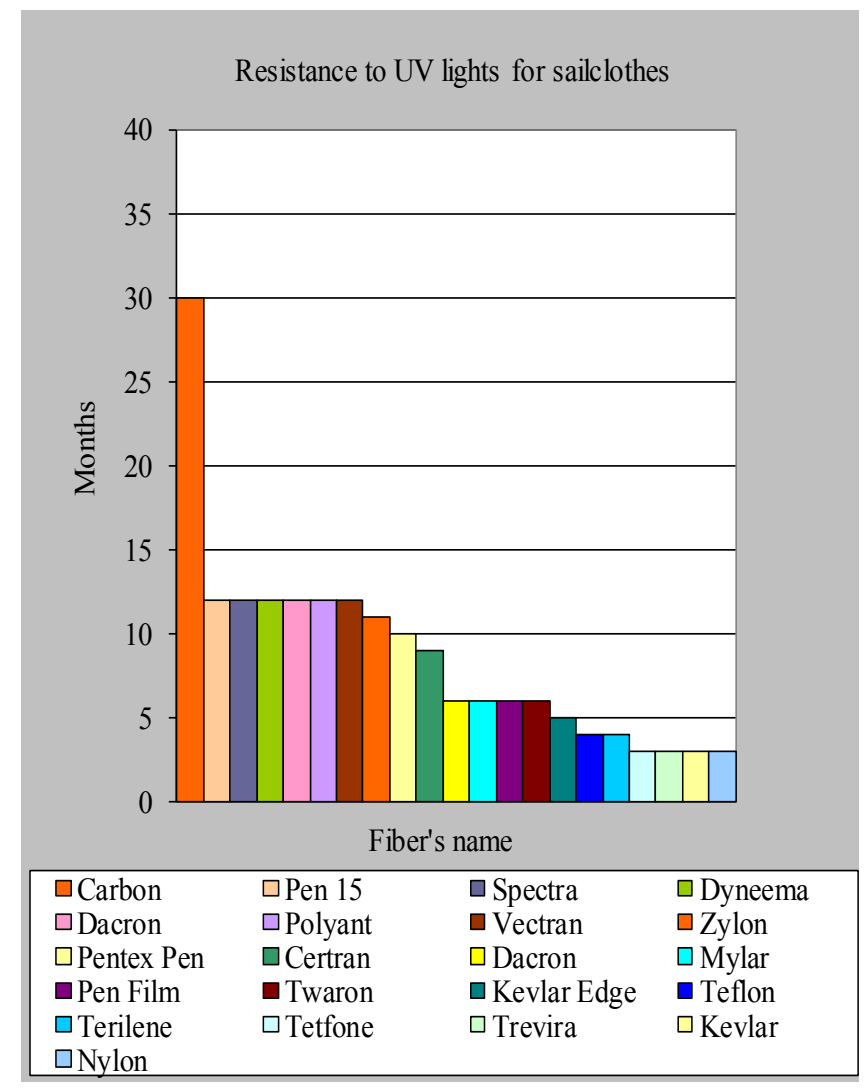

Fig. 2. Resistance to ultraviolet (UV) lights for sailcloth (origin: prepared by the author based on [2-7])

\section{Research results}

The fabric of the sailcloth coverage has a problem from resistant. As the sailcloth is important, yarns try to reform, it is a result of stretch. Fibers must be proof to resistant and stretching.

In Table 1 (origin: prepared by author based on [2-7]) more popular (after the use in international and world regattas) names of sailing materials and laminates used for sewing in yachting are given. 
Table 1

Main fibers and laminates used for sewing sails in yachting (prices shown in 2015)

\begin{tabular}{|c|c|c|c|c|c|c|}
\hline Fibers and Laminates & Class of fibers & $\begin{array}{l}\text { Company- } \\
\text { designers }\end{array}$ & $\begin{array}{l}\text { Resistance to } \\
\text { UV, month }\end{array}$ & $\begin{array}{c}\text { Modulus of } \\
\text { elasticity, } \mathbf{H} / \mathbf{m}^{2}\end{array}$ & $\begin{array}{c}\text { Gap of } \\
\text { strength, } H / \mathbf{m}^{2}\end{array}$ & $\begin{array}{l}\text { Cost of yarn/roll } \\
\text { for } 1 \mathrm{~kg}, \$\end{array}$ \\
\hline Dacron & Polyester & DuPont & 6 & 80 & $5-8$ & $9-11$ \\
\hline Type 52 & Polyester & DuPont & 6 & 80 & $5-8$ & $9-11$ \\
\hline Pentex & Polyester & DuPont & 4 & 250 & 9 & $28-45$ \\
\hline Teflon & Polyester & DuPont & 4 & 150 & 7 & $15-22$ \\
\hline Terilene & Polyester & DuPont & 4 & 120 & 7 & $10-12$ \\
\hline Tetfone & Polyester & DuPont & 3 & 120 & 7 & $10-12$ \\
\hline Trevira & Polyester & DuPont & 3 & 140 & 8 & $11-13$ \\
\hline Diolen & Polyester & DuPont & 3 & 135 & 8 & $9-10$ \\
\hline Mylar & Films & DuPont & 6 & 81 & $5-8$ & $10-11$ \\
\hline Pen Film & Films & DuPont & 6 & 81 & $5-8$ & 10 \\
\hline Kevlar & Aramids & DuPont & 3 & $460-520$ & 24 & $80-120$ \\
\hline Kevlar Edge & Aramids & DuPont & 5 & 550 & 24 & $90-130$ \\
\hline Kevlar Type 29 & Aramids & DuPont & 5 & 400 & 22 & $60-70$ \\
\hline $\begin{array}{c}\text { Kevlar Type } 49 \\
\text { (high module class) }\end{array}$ & Aramids & DuPont & 5 & 400 & 22 & $60-70$ \\
\hline Kevlar Type 129 & Aramids & DuPont & 5 & 400 & 22 & $60-70$ \\
\hline Kevlar Type 149 & Aramids & DuPont & 5 & 400 & 22 & $60-70$ \\
\hline Kevlar Type 159 & Aramids & DuPont & 5 & 400 & 22 & $60-70$ \\
\hline $\begin{array}{l}\text { Twaron (high modulus } \\
\text { Twaron( HMT)) }\end{array}$ & Aramids & Teigin, Japan & 6 & 550 & 24 & $130-140$ \\
\hline Technora & Aramids & Teijin, Japan & 2 & 574 & 27 & $60-95$ \\
\hline Carbon & Carbon Fibers & $\begin{array}{l}\text { USA, } \\
\text { Japan }\end{array}$ & unresponsive & $1500-3000$ & $10-24$ & $>150$ \\
\hline $\begin{array}{l}\text { Racing } \\
\text { laminate Carbon14 by batch } \\
\text { Maxx (Contender Sailcloth) }\end{array}$ & Carbon Fibers & USA & 12 & 1000 & 40 & 150 \\
\hline $\begin{array}{l}\text { Pen15 by batch Maxx } \\
\text { (Contender Sailcloth) }\end{array}$ & Carbon Fibers & USA & 12 & 1000 & 42 & 150 \\
\hline Nylon & Synthetic fibers & USA & 3 & 20 & $7-9$ & 9 \\
\hline Spectra & Polyethylene & $\begin{array}{l}\text { Honeywell, } \\
\text { USA }\end{array}$ & 12 & $1400-2200$ & $32-35$ & $90-120$ \\
\hline Dyneema & Polyethylene & $\begin{array}{l}\text { DSM, } \\
\text { Holland }\end{array}$ & 12 & 1200 & $35-42$ & $60-95$ \\
\hline Certran & Polyethylene & USA & 9 & 750 & 33 & 90 \\
\hline Pentex (Pen Fiber) & Polyethylene & $\begin{array}{l}\text { Honeywell, } \\
\text { USA }\end{array}$ & 10 & 800 & 35 & 90 \\
\hline $\begin{array}{l}\text { Dacronwith arming Kevlar } \\
\quad \text { (Challenge Sailcloth) }\end{array}$ & $\begin{array}{l}\text { Fiber } \\
\text { reinforce d }\end{array}$ & USA & 12 & 1000 & 40 & 80 \\
\hline $\begin{array}{c}\text { Dimention Polyant } \\
\text { (model racing laminate) }\end{array}$ & $\begin{array}{l}\text { Fiber } \\
\text { reinforce d }\end{array}$ & USA & 12 & 800 & 42 & 120 \\
\hline Vectran & $\begin{array}{l}\text { Liquid } \\
\text { Crystal } \\
\text { Polymer }\end{array}$ & $\begin{array}{l}\text { Celanese } \\
\text { Corporation, } \\
\text { USA }\end{array}$ & 12 & 600 & 25 & $>120$ \\
\hline $\begin{array}{l}\text { Zylon } \\
(\mathrm{PBO})\end{array}$ & $\begin{array}{l}\text { Liquid } \\
\text { Crystal } \\
\text { Polymer }\end{array}$ & $\begin{array}{l}\text { Toyobo, } \\
\text { Zylon, Japan }\end{array}$ & 11 & 550 & 24 & 110 \\
\hline
\end{tabular}


In Fig. 3 can see modulus of elasticity in choosing the right sailcloth (origin: prepared by the author based on [2-7]).

The module (modulus) is a size of durability or elasticity of fabric. High value of the module $=$ the low stretch [2-5].

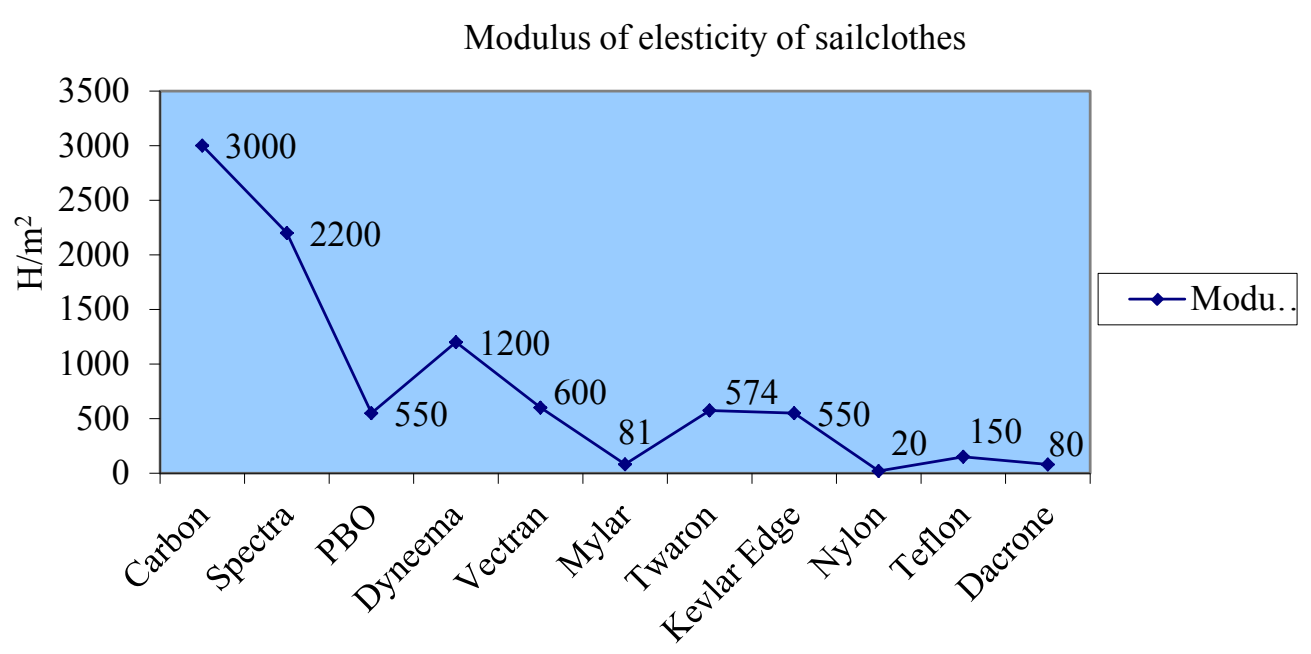

Fiber's name

Fig. 3. Modulus of elasticity for sail cloth

Bainbridge's brand name has a superior range of performance spinnaker Nylons.

Carbon used the most extensively in composite engineering and recently introduced to the sailcloth market (Fig. 3). Dacron-DuPont's trade named for Polyester fiber. There are highest numbers of representing heavier yarns: DIAX-Bainbridge's brand name for laminates with a 45-degree diagonal scrim; DIAX2-Bainbridge's new brand of double DIAX reinforced cross cut race and cruise laminates. mid fibers.

Dyneema - super strong Polyethylene fiber made by DSM is up to $40 \%$ stronger than ara-

Aramids has to resistant to UV and moisture [2-7].

Kevlar-DuPont's trade name is for a family of high-strength Aramid fibers.

Laminate - a stratified fabric made out of relating rough linens and/or with one or two band linens. It's: DIAX2 Load Path- new technology of sails, that is combined with DIAX2 of laminates and complete length of Load Path by brief fibers; LSP are the names of laminates of Diax, using fibers of Pentex. It has the opportunity to the stretch or elasticity of factory and high modulus - low stretch [2-7].

Polyester - a strong, reliable and inexpensive fiber for cruising and low-tech racing laminates, has woven sailcloth and the most stretch resistant.

Scrim - non woven, formed sheet of yarns held together with resin. There are: Spectra - a highly modified Polyethylene fiber developed by Allied Corporation; Taffeta - a light woven fabric used on laminates to add durability and abrasion resistance; Tenacity - breaking strength of a yarn or fabric stated in force per unit of the cross-sectional area.

Tensile Strength has the ability of a fiber, yarn or fabric to resist breaking under tension [2-7]. Technora is Aramid fibers with lower modulus but higher durability than Twaron. Twaron from the family of aramid fibers make by Akzo and used in Bainbridge DIAX-HMT racing laminates.

\section{Conclusions}

Sails are a key strategic element for a kind management of a boat. There are many factors that can weaken fabric of coverage of sail. There are: used fabrics of sails, UV lights, etc. If fibers were already weak, it will be torn easier on a sailing vessel. An exposure of sails to the UV lights 
is a primary factor that weakens a canvas. Sails need to be replaced far more often, it's placing becomes the same better.

Many types of different coverage will be used for raising of sail. The different types of fabric are used depending on requirements for a sail. Main requirements for the different types of canvas are: resistance, weight, punctuality and border of durability, resistance of degradation from UV lights, prices and design. Each of them is very important for the different uses of sails. The resistance is important, because a sail will stand against wind that increases speed of sailing boat. Resistance of degradation from the UV lights is also important for the sailing boats. According to yacht experts, price, a design is not important criteria for quality of sails.

Development of chemical industry and appearance of new technologies allowed to do a quality jump in area of making of sails. Sails are created by reliable and strong, to maintain any loading. They must work in any weather terms. Double guy-sutures, reinforcing network of strong fibers, in combination with the newest modern technologies that present at the market most companies for sewing of sails are basis that allows to the sail to execute any tasks that can only think of for them.

Enough positions are described in the real article, for that any yachtsman will be able to define as for itself so for the command as far as strong sails, coming from the presented tables and diagrams. One man - skipper participates in the choice of fabric. Only he can define as far as the effective is fabric for sewing/of order of new sail.

Today, fabrics that does not give large self-control at the action of the stretching forces, directed under a corner to direction of filaments from that linen is woven, are especially valued today. Taking into account all factors, including a stretch and rapid wear/break of fabrics on regattas, yachtsmen have a right to choose of highest materials for the boat. In fact, the torn sails on competitions are this double defeat, as for a participant so for all command.

The presented article demonstrates to the yachtsmen of yacht races facts as numbers that will help correctly to do a choice toward the most durable and enduring material for sewing of sails. Sails that a skipper takes hard - over must be able to provide optimal implementation of tasks, due to all terms.

\section{References}

[1] Bond, B. (1989). Spravochnik yachtsmen. Leningrad: Sudostroenie, 336.

[2] Yeroshkina, S. (2016). Technical features of rigged yacht by categories and classes. The actual problems of regional economy development, 2 (12), 98-111. doi: 10.15330/apred.2.12.98-111

[3] Yeroshkina, S. (2016). World training sailing boats. The actual problems of regional economy development, 2 (12), 111-120. doi: 10.15330/apred.2.12.111-120

[4] Yeroshkina, S. H. (2017). Features of the world sailing regatta by yacht. Collection of Scientific Publications NUS, 3. Available at: http://jnn.nuos.edu.ua/article/view/92732/88481 doi: 10.15589/jnn20160304

[5] Yeroshkina, S. H. (2016). Current state and special features of the world yachting. Collection of Scientific Publications NUS, 4. Available at: http://jnn.nuos.edu.ua/article/view/94913/93015 doi: 10.15589/ jnn20160403

[6] Jang, B. Z. (1994). Advanced Polymer Composites: Principles and Applications. ASM International, Materials Park, $\mathrm{OH}$.

[7] Odian, G. (1991). Principles of Polymerization. New York: J. Wiley, 768.

[8] Fabric Guide. Available at: http://www.doylesails.com/design/fabric.html

[9] What Sails are Made of and Their Uses. Available at: https://www.getmyboat.com/resources/ tips-for-owners/291/what- sails-are-made-of-and-their-uses

[10] Sail Cloth and Alternate Materials. Available at: http://www.pdracer.com/sail/material/

[11] Sail Cloth \& Sail Material by Jeckells The Sailmakers. Available at: http://www.jeckells.co.uk/ sails/sail-cloth/

[12] Yacht Sails. Available at: http://www.kempsails.com/yacht-sails.html

[13] Kevlar, Carbon, 3DL...sails explained. Available at: http://blog.sailinglogic.co.uk/post/2012/ 02/01/Kevlar-Carbon-3DLsails-explained.aspx\#.WMLsVNSLTDf 